\title{
INTERNATIONAL BUSINESS: RAISING CULTURAL AWARENESS IN GLOBAL NEGOTIATING
}

\author{
Jovana Gardašević*, Jelena Vapa-Tankosić \\ University Business Academy in Novi Sad, \\ Faculty of Economics and Engineering Management, \\ 2 Cvećarska Street, Novi Sad, Serbia
}

\begin{abstract}
:
The global marketplace is a fast-growing and rapidly changing field. Global negotiation is a process where each party from two or more different countries involved in negotiating tries to gain an advantage for itself by the end of the process. The process of global negotiating differs from culture to culture in terms of language, different types of communication (verbal and nonverbal), negotiating style, approaches to problem - solving, etc. The aspects of culture that are of vital importance for global negotiating are attitudes and beliefs, religion, material culture, and language. This paper should encourage better understanding of the process of negotiation: it defines the negotiation process, identifies the issues that are subject to negotiation and mentions the stages of negotiation. It discusses the importance of developing cultural awareness prior to negotiating internationally through descriptive overview of all aspects of culture. It gives examples of differences in global negotiating and doing business worldwide. The purpose of this paper is to show theoretically the connection between these terms and provide information that will prevent business people from making mistakes and pitfalls in international negotiation process.
\end{abstract}

\section{Key words:}

negotiating,

global negotiating,

international business,

culture.

\section{INTRODUCTION}

The growth of international business has been dramatic and straightforward. When doing business internationally, communication takes place between individuals, not cultures. However, cultural awareness can help you to predict how business people belonging to a certain culture will act, negotiate, and make decisions. The first part of this work puts an emphasis on understanding the negotiation process through its definition, issues that can be negotiated and stages of negotiating. The second part is more oriented towards international negotiations and aspects of culture that make global negotiations different. Finally, the third part is about some good practices and examples of how negotiating and business differ from country to country, from region to region. Prior to initiating negotiations in another country, it is recommended to identify and overcome all communication and cultural gaps in order to enable business people to conduct their businesses more efficiently. It is necessary to possess relevant information on what makes global negotiating different in order to do business successfully on a global scale.

\section{UNDERSTANDING THE NEGOTIATION PROCESS}

Negotiation is conceived as a process in which at least one individual tries to persuade another one to change his or her ideas or behaviour and it often involves one person attempting to persuade another one into signing a particular contract or making a 
particular decision. Negotiation becomes cross-cultural when the parties involved belong to different cultures, and thus do not share the same patterns of thinking, feeling, and behaving (Casse, 1981). Gulbro and Herbig (1996) are frequent writers in this area. One of their studies argues that negotiators must devote certain amount of time to the negotiation process, preparation, and should improve their knowledge about the other party's culture in order to boost their odds of success. Large companies are found to be more successful in this endeavor than smaller ones (Gulbro \& Herbig, 1996). Negotiating is the process you follow in order to get someone to do what you want her/him to do. It entails communicating back and forth for the purpose of reaching an agreement that is acceptable to both sides. In cases of import / export, that agreement may be related to the price you want to pay a supplier for a product or what you want someone to pay for a product that you are selling. Negotiating has to do with persuading while making sure that the other side feels good about the outcome (Capela, 2012).

According to Capela (2012), although deals can be complex, there are only a few main issues you can negotiate about:

1. Territory: You can negotiate about whether you will have any limits on where and to whom you may sell the product.

2. Exclusive or nonexclusive: If you are an importer, you may negotiate over whether you have exclusive or nonexclusive distribution rights.

3. Performance: Discuss minimum performance requirements. For instance, if I am a U.S. distributor appointed by Bolivian pewter manufacturer, will I be required to meet certain sales targets during the term of the agreement? What happens if I do not meet these sales targets?

4. Products: Discuss the product covered within the agreement, including its specifications. Talk about quality, service, and training.

5. Price and payment: Set down a detailed price schedule and payment terms.

6. Shipping terms, risk of loss: Shipping terms provide information on the expenses that are the responsibility of each party in the transaction. They also indicate where title will pass from the exporter to the importer.

7. Restrictions on carrying competitive products: In this part of the negotiation process, you can clearly explain what kinds of products are considered competitive products.

8. Governing law and languages: Different countries have different laws on contracts. Negotiate which country's law governs the agreement and whether both parties will adhere to some international standards.

9. Provisions for dispute settlement: Most disputes between parties arise out of different expectations regarding their obligations to each other. The negotiations need to specify each party's expectations in order to reduce the possibility of surprise.

10. Duration of contract and termination: Discuss the length of the agreement and the condidtions under which it can be cancelled or renewed.

Capela (2012) also says that both domestic and international negotiations proceed through six stages:

- Research.

- Build a relationship.

- Exchange infortmation and make the first offer.

- Persuasion.

- Make concessions.

- Come to an agreement.

When it comes to the stages of the negotiation process, Williams (1991) considers that after adopting a strategy, it is time to go in for the actual negotiation process. He identifys the four main stages during the negotiation process.

- Orientation and Positioning. Orientation takes place when the parties first meet, introduce themselves and exchange pleasantries. Positioning commences when either party states its offer on the negotiation table.

- Argumentation. Here, the argument is not a fierce one. It is the stage where each party tries to understand the position of the other party. This is where the issues related to the transactions are discussed such as the price of goods or applicable law etc.

- Emergence and Crisis. At this stage, parties begin to see signals showing whether they will reach an agreement or not.

- Agreement or Breakdown. This is the final stage where the parties either successfully reach an agreement or fail and the negotiation breaks down. It is important to state that a successful negotiation is not a 'win-lose' but a problem-solving approach to a 'win-win' out- 
come. A good outcome shall bring benefit to both parties and neither party is of the opinion that it has signed a less advantageous contract. The agreement should encourage a good relationship and be flexible enough to deal with the expected or unexpected future changes (Ghauri \& Usunier, 2008).

We shall move on to the planning stage of negotiation process. Planning is the process of setting an objective and identifying the courses of action that are necessary to accomplish it. It is extremely important as it provides us with guidelines and standards that could be used to measure performance. All parties in the negotiation process use the planning stage to prepare their side of the discussion with the aim of gaining an advantage by the time the negotiation is concluded. Planning negotiations is a simple four step process:

1. Identify the issue.

2. Set up priorities.

3. Identify an acceptable settlement range - i.e., an area in which agreement is possible.

4. Develop strategies and approaches for reaching an agreement on each of the elements being negotiated, putting an emphasis on the priorities you have choosen (Capela, 2012).

Steps in the negotiation process are described differently by various authors. At least three steps are traditionally identified, as follows:

1. planning or preparation,

2. negotiation, bargaining, interaction, and

3. striking a deal. Some scholars suggest other steps, such as relational positioning, identifying the problem, generating solutions, and reaching an agreement (Adair \& Brett, 2005).

\section{DEVELOPING CULTURAL AWARENESS BEFORE NEGOTIATING}

A number of studies examine factors that determine success of cross-cultural negotiations. Different authors state different elements of culture. In this paper, we examine the traditional elements of the culture that are crucial for global negotiation process: religion, language and material culture. Some authors such as Ball and McCulloch (2002) said that legal characteristics and political structure are also the elements of culture.

Religion is one of the most important aspects of culture that differs around the world. Awareness of some of the basic beliefs and attitudes of the major religions in the world will help you to understand better why attitudes vary from country to country, from region to region. The religion establishes moral codex, ethics, the human conduct and their working habits. It is a crucial factor for global negotiating due to its determination of national or individual behaviour, attitudes, the way of doing business, the way of wearing clothes, the way of living, the way of interacting with other people etc. The most representative religions are: Christianity, Islam, and Hinduism. Thus, before we decide to do business internationally, we need to be familiar with all global religious customs and beliefs in order to be able to decide which business strategy to use, how to communicate with potential partners and what to demand through negotiation process regarding the main issues being negotiated, as mentioned in the previous section.

In order to successfully conclude a business deal, a labor agreement or a government contract with foreigners, who greatly differ from us, requires a considerable amount of communication skills. In order to successfully manage such negotiations, business people need to know how to influence and communicate with members of the culture other than their own (Saee, 2008).

Kotler (2006) emphasizes that there are over 200 different languages around the world and over 3000 different language variants. One of the most important issues concerning global negotiation process is breaking the language barriers. The knowledge of foreign languages helps business people to communicate successfully and understand correctly what the other party wants to say or demand. The usage of a language is mostly seen as an international marketing concept. For instance, it is observed in advertising or branding, or even in product designing. However, its usage is most common in global negotiating and international correspondence. We can find different language structures in written documentation and presentations or use it as a verbal communication tool when meeting with our business partners. Communication can be verbal or nonverbal. Differences in communication patterns have a considerable impact on the international negotiation process. It is also necessary to identify the language used in the official version of the contract.

When negotiating with individuals from other countries, we will probably notice a lot of differences in their business culture and etiquette. Cultural awareness and sensitivity facilitate the exchange of information by examining the other party, exploring business culture and building relationships with partners. 
These activities are part of the six-stage international negotiation process, which was mentioned in the first section of this paper.

Material Culture is everything that human being creates and shapes with his/her hands and it completely differs from spiritual culture - the product of one's mind. Material Culture includes technology (how people make things) and economics (who, how and why makes). Some cultures prefer holding the material goods like the U.S. while others give priority to family relationships and friendships, as is the case in Serbia. The richer the one country is, the higher life standard it has. The higher life standard one country has, the higher the prices of products and services are. This information is crucial in the process of negotiation when we want to discuss the price and payment terms. One needs to be conversant with macroeconomics as well as with other social or cultural opportunities of one country.

\section{THE CHALLENGES OF GLOBAL NEGOTIATING IN THE CONTEXT OF INTERNATIONAL BUSINESS}

In spoken and written communication, the use of inappropriate words or incorrect grammar is not the only concern. The meaning of the message often depends on the context - the set of circumstances surrounding those words. Sometimes, the culture is not primarily defined in terms of national culture, but in terms of collectivist or individualist culture, or high or low context culture. In high - context culture, information is included in the context of the message, with little being communicated in the explicit words of the message. The following countries are typical examples of higher - context culture: African, Arab, Brazilian, Chinese, Filipino, Finnish, French, French - Canadian, Greek, Hungarian, Indian, Italian, Japanese, Korean, Latin American, Russian, Spanish, Thai, Turkish. If we are talking about low - context culture, the words the sender uses explicitly convey the message to the receiver. Some of the most typical low - context cultures are as follows: American, Australian, English, English - Canadian, German, Irish, New Zealand, Scandinavian (Capela, 2012).

Non-verbal behaviour represents communication other than verbal. It refers to the manner in which negotiators express words rather than the words themselves. Non-verbal behaviour conveys multiple messages, many of them are responded to at a subconscious level. Negotiators frequently respond more emotionally and powerfully to non-verbal rather than verbal messages. As with verbal behavior, non-verbal behaviour also differs considerably across cultures (Saee, 2008). Nonverbal communication can tell business people something that the spoken language cannot-if they understand it. It is sometimes called body language. Non-verbal behavior subsumes tone of voice, facial expressions, body distance, dressing code, gestures, timing, silences and symbols (Adler \& Gundersen, 2008). Some of them shall be analyzed in this paper.

Firstly, we shall talk about the gestures. For instance, American and most European citizens understand the thumbs - up gesture to mean that everything is "all right", but in southern Italy and Greece, it transmits the message for which we reserve the middle finger.

General appearance and dressing code is the next one. As we live in a material world, physical appearance is the essence of the first impression. All cultures are concerned with how they look and make judgments based on someone's physical appearance. We should consider different cultural standards on what is attractive in dress and what constitutes modesty. In the U.S., the naked eye could see their carelessness and neglect about this matter. They are traditionally not interested in how they look and from a cultural point of view, are generally not considered a very stylish nation. On the other hand, the French or Italian have that status and etiquette (Gardašević, 2013).

When it comes to posture, we can say that cultures interpret body posture in different ways. For instance, bowing is an indicator of ranking in Japan, while slouching is considered extremely rude in most Northern European countries. Having your hands in your pockets is considered a sign of disrespect in Turkey. Moreover, sitting with legs crossed is considered offensive in Ghana and Turkey, while in most Southeastern countries such as Serbia or Croatia, it is viewed as a symbol of femininity and grace (Gardašević, 2013).

Other important cultural characteristics for the process of negotiation that we are going to explain are: time, individualism $v$ s. collectivism, orderliness and conformity, communication patterns etc. We could also analyze the influence of time and pace of negotiations. Negotiation tactics are important when one party is under time constraint. Cultures differ considerably in their use of time. The American, Australian, German and the Swiss are usually fast-paced and extremely punctual, with no space for delay. A negotiation session that is to start at 11 a.m. on 
Monday will start exactly at 11 a.m. that day. On the other hand, in Latin American countries, starting the negotiation process an hour later may be considered normal and in some cases expected. The American people are preoccupied with deadlines, which can be a crucial liability when negotiating with individuals from other countries. One study focused on the effects of time pressure and accountability on competitiveness of interaction and outcomes. It was found that when negotiators negotiated just for themselves, time pressure made them less competitive and a greater proportion of negotiations lead to an agreement. However, when negotiators negotiated on behalf of "constituents", the opposite was found. Time pressure resulted in more competitive behaviour and a lower proportion of agreements (Mosterd \& Rutte, 2000).

Furthermore, individualism or collectivism also has significant meanings for global negotiations. The American people build their success on talking directly to the decision - maker. A negotiator usually talks to the top person who represents the company or belongs to the top management. As he/she is a decision - maker, he/she has the power to negotiate with other negotiators and make deals.

Formalities help people to establish friendly relationships, which many cultures consider necessary for business negotiations. However, this can ruin good business practice if the country is not oriented towards formalities. For instance, the Japanese pay considerable attention to the presentation of business cards. They consider it extremely important for the beginning of the negotiation process. They also emphasize the relationship, as they belong to the collectivist culture and foster community spirit, and getting to know if the other person brings order and predictability to the negotiation process. On the other hand, negotiators from Canada, Germany, Switzerland, and the U.S. place greater emphasis on the content of the negotiations rather than on the procedure (Capela, 2012).

\section{CONCLUSION}

International business in general, especially the international negotiating, represents not only economic but also cultural and social phenomenon. The purpose of this paper is to show theoretically that all aspects of culture are of vital importance for business people and companies in their international approach to negotiating, starting from language and understanding, attitudes and beliefs, religion to the elements of material culture. The impact of the culture on international negotiation and decision - making process is rapidly growing, especially in the time we are living in, which is characterized by the high level of trade liberalization, market expansion, globalization, economic integration, international business and marketing - oriented companies that coordinate their decisions with the requirements of their business partners or previous consumers. We are also living in a period of the improved technologies and communication media, thus bringing greater opportunities for tremendous interaction with people around the world. However, cultural awareness will assist business people in predicting how people in certain culture will act, negotiate, and make decisions. It is essential to possess some specific communication skills and be all around in the knowledge of world culture (to know how or whether to use verbal or nonverbal communication, whether to be late or punctual, whether to speak to the top management or members of a team, etc.) Understanding how someone addresses an issue or even simply how that person goes about making decisions based on communication and cultural grounds will give you an edge. Therefore, there is a tremendous connection between global negotiating, international business and culture.

\section{REFERENCES}

Adair, W., \& Brett, J. (2005). The negotiation dance: time, culture, and behavioral sequences in negotiation. Organization Science. 16(1), 33-52. DOI: 10.1287/ orsc. 1040.0102

Adler, N.J., \& Gundersen, A. (2008). International dimensions of organizational behavior. Mason, Ohio: Thomson.

Ball, D.A., \& McCulloch, W.H. (2002). International business: Introduction and essentials. Boston: McGraw-Hill.

Capela, J.J. (2012). Import / export kit for dummies. Hoboken, NJ: John Wiley \& Sons.

Casse, P. (1981). Training for the cross - cultural mind: A handbook for cross-cultural trainers and consultants. Washington, DC: Society for Intercultural Education, Training and Research.

Gardašević, J. (2013). Global Negotiating - Communication and Culture. Ekonomija: teorija i praksa. 6(1), 47-58.

Ghauri, P.N., \& Usunier, J.C. (2008). International business negotiations. Bingley: Emerald.

Gulbro, R. \& Herbig, P. (1996). Negotiating successfully in cross-cultural situations. Industrial Marketing Management. 25(3), 235-241. DOI: 10.1016/00198501(95)00081-X 
Kotler, P., \& Keler, K.L. (2006). Marketing menadžment. Beograd: Data Status.

Mosterd, I., \& Rutte, C.G. (2000). Effects of time pressure and accountability to constituents on negotiation. International Journal of Conflict Management. 11(3), 227247. DOI: $10.1108 /$ eb022841
Saee, J. (2008). Best practice in global negotiation strategies for leaders and managers in the $21^{\text {st }}$ century. Journal of Business Economics and Management. 9(4), 309-318, DOI: 10.3846/1611-1699.2008.9.309-318

Williams, G.R. (1991). Legal Negotiation and Settlement. Minnesota, USA: West Publishing.

\section{MEĐUNARODNO POSLOVANJE:}

\section{PODIZANJE KULTURNE SVESTI U PROCESU GLOBALNOG PREGOVARANJA}

\section{Rezime:}

Globalno tržište predstavlja segment koji se neprekidno menja i razvija. U procesu globalnog pregovaranja svaka strana, iz dve ili više različitih zemalja, pokušava da stekne prednost do kraja pregovora. Ovakav vid komunikacije (verbalne ili neverbalne) varira od zemlje do zemlje, od kulture do kulture u pogledu jezika, pregovaračkog stila, pristupa rešavanju problema, itd. Aspekti kulture koji su bitni za međunarodne pregovore su stavovi, uverenja, religija, materijalna kultura i jezik. Ovaj rad ima za cilj da doprinese što boljem razumevanju procesa pregovaranja: definiše tok pregovaranja, identifikuje pitanja koja su predmet pregovora i imenuje faze u procesu pregovaranja. U radu se govori o značaju razvoja kulturne svesti pre vođenja međunarodnih pregovora kroz slikovit prikaz značajnih kulturnih aspekata. Takođe, autori nastoje da ukažu na primere različitosti koje postoje u globalnom procesu pregovaranja i međunarodnom poslovanju uopšte, kao i na izazove sa kojima se susreću učesnici međunarodnih pregovora. Svrha rada jeste da teorijski prikaže vezu imeđu pomenutih termina kao i da poslovnim ljudima iz međunarodnog okruženja pruži neophodne informacije u cilju izbegavanja grešaka u međunarodnom pregovaranju.

\section{Ključne reči:}

pregovaranje, globalno pregovaranje, međunarodno poslovanje, kultura.

Received: February 10, 2015. Correction: March 1, 2015. Accepted: March 10, 2015. 